\title{
Review
}

\section{HCV immunology-Death and the maiden T cell}

\author{
C Willberg, ${ }^{1}$ E Barnes ${ }^{1}$ and P Klenerman ${ }^{\star, 1}$ \\ 1 Nuffield Department of Medicine, Peter Medawar Building for Pathogen \\ Research, University of Oxford, South Parks Road, Oxford OX1 3SY \\ * Corresponding author: P Klenerman; Tel: 01865 281885; Fax: 01865 281236; \\ E-mail: Klener@molbiol.ox.ac.uk
}

Received 23.4.02; revised 29.5.02; accepted 30.5.02 Edited by M Piacentini

\begin{abstract}
Cellular immune responses play an important role in the control of hepatitis C virus (HCV), although in the majority of cases they ultimately fail. We examine the mechanisms by which virus-specific $T$ cells may interact with a cell that is infected with HCV and how this interaction may explain the success and failure of the immune response. As an infected cell presenting foreign antigen, the hepatocyte will interact with a large number of lymphocytes, both by direct cell to cell contact and by indirect means through the secretion of cytokines and chemokines. These interactions may lead on the one hand to the death of infected hepatocytes or suppression of viral replication and on the other hand to the death of T lymphocytes or down regulation of their function. We suggest that activation of lymphocytes in lymphoid organs leads to generation of effector T cells (positive loop), while at the same time presentation of antigen in the liver either on hepatocytes or other specialised antigen presenting cells depresses these responses (negative loop). This model helps to explain both the specific phenotype and low frequencies of HCV specific CTL in chronic infection, through early elimination of cells before expansion and maturation can occur. The outcome of HCV infection is likely to result from the early balance between these two simultaneous loops.

Cell Death and Differentiation (2003) 10, S39-S47. doi:10.1038/ sj.cdd. 4401122
\end{abstract}

Keywords: hepatitis $\mathrm{C}$ virus; $\mathrm{CD}^{+} \mathrm{T}$ lymphocytes; $\mathrm{CD}^{+} \mathrm{T}$ lymphocytes; hepatocytes; immune escape; hepatocyte

Abbreviations: APC, antigen presenting cell; CMV, cytomegalovirus; CTL, cytotoxic T lymphocytes; EBV, Epstein-Barr virus; $\mathrm{HBV}$, hepatitis $B$ virus; $\mathrm{HCV}$, hepatitis $\mathrm{C}$ virus; IFN, interferon; IL, interleukin; IP-10, IFN- $\gamma$ induced protein 10; LCMV, lymphocytic choriomeningitis virus; LSEC, liver sinusoidal epithelial cells; MHC, major histocompatibility complex; MIG, monokine induced by IFN- $\gamma$; PBMC, peripheral blood mononuclearcells; $P C R$, polymerase chain reaction

\section{Introduction}

Hepatitis C virus affects an estimated 170 million people worldwide. ${ }^{1}$ Unlike other common hepatitis viruses (particularly $A$ and $B$ ), it sets up persistent infection in the majority of those infected. Hepatitis B virus (HBV) causes severe acute hepatitis and can become persistent, particularly if acquired in early life, but in contrast to $\mathrm{HCV}$, it is normally controlled if acquired in adult life. Because it so readily becomes persistent, and no vaccine exists, $\mathrm{HCV}$ has become a major public health problem in many countries. The problem is particularly acute in some, such as Egypt, where iatrogenic spread was common and where the prevalence may be up to $30 \%$ in some populations. ${ }^{2}$

Once HCV persistence is established-the case in about $85 \%$ of those infected-patients fall broadly into two groups. A minority of patients develop progressive liver inflammation, fibrosis, and ultimately cirrhosis with liver failure or liver cancer. The progression is generally slow in immunocompetent hosts (over decades), although can progress more rapidly in the immunosuppressed. The majority however, remain persistently viraemic, but develop much lower levels of inflammation and fibrosis and may remain asymptomatic lifelong. ${ }^{3}$

\section{Immune responses to $\mathrm{HCV}$}

Immune responses to $\mathrm{HCV}$ may play an important role at various stages of infection: there is emerging evidence that during acute infection, cellular immune responses are important in the initial control of viral replication in those patients who subsequently control infection. In the chronic phase of infection, immune responses potentially determine the rate of progression of disease both by limiting viral replication and by contributing to immunopathology. Finally, during combination therapy, cellular immune responses may contribute to the success or failure of treatment.

\section{Components of the immune response}

The various components contributing to an effective antiviral immune response against a hepatotropic virus in model systems such as lymphocytic choriomeningitis virus have been reviewed recently elsewhere. ${ }^{4}$

In summary, it is essential that such a response comprises: (a) Effective innate immune effector mechanisms such as Type I interferons; ${ }^{5}$ (b) Anatomically intact lymphoid organs in which to generate efficient antiviral $B$ and T cell responses; ${ }^{6}$ (c) An antibody response, which has some degree of neutralising capacity (even weak neutralising capacity may be important in certain animal models); ${ }^{7,8}$ (d) Intact antigen presentation pathways; (e) A strong and sustained CD4+ T helper response; ${ }^{9}$ (f) A strong and sustained CD8+ T lymphocyte (CTL) response. ${ }^{8}$ 
These components must act in concert in order to gain long term control of viruses. The use of gene targeted knock-outs and depletion experiments in animal models have convincingly shown the interdependence of the various immune mediators. ${ }^{8,10}$ For the purposes of this discussion, however, we are concentrating on conventional $T$ cell subsets (CD4+ $T$ helper cells and CD8+ cytotoxic $T$ lymphocytes (CTL)). This is firstly because most data exists in this area and these data suggest a critical role for these cells. It is also because we hypothesise that the molecular interactions at the interface between an infected hepatocyte and an antigen-specific $\mathrm{T}$ cell play a crucial role in determining the outcome of $\mathrm{HCV}$ infection.

\section{CTL responses (successful)}

CD8+ $T$ lymphocytes (CTL) recognise virally infected cells through the presentation of viral peptides in the groove of host MHC Class I molecules. In certain uninfected antigen presenting cells cross presentation may also occur-i.e. presentation of exogenous proteins through the Class I pathway. CTL, when they recognise their targets, typically release interferon gamma, chemokines such as RANTES and MIP-1 $\alpha$, and cause death of their target cell. These mechanisms serve to eliminate virus infected cells or suppress viral replication in neighbouring cells. Because CTL are very sensitive to low levels of viral peptide, this recognition and effector function can potentially occur at an early stage in viral replication.

Until recently, CTL were identified through functional assays such as ELISpot (release of interferon-gamma) or cytolysis, but more recently, the use of Class I peptide tetramers has allowed direct ex vivo detection independent of function. This technology has allowed also detailed phenotyping of the surface expression of a range of molecules on antigen specific CTL (reviewed $\mathrm{in}^{11}$ ).

In acute disease, where this has been studied, using such techniques, vigorous HCV-specific CTL responses have been observed. ${ }^{12-15}$ These have been particularly associated with control of viremia, but substantial responses have also been seen in those who fail to control virus. ${ }^{13}$ Multiple epitopes may be targeted simultaneously. ${ }^{12}$ The response shows dynamics typical of many other acute infections, with highly activated CTL seen at the time of acute disease in frequencies of up to $7 \%$, and rapid contraction of these populations thereafter. In those who control virus, memory populations are maintained long term. ${ }^{12}$ Although not conclusive, these data suggest that CTL play an important role in the initial resolution of $\mathrm{HCV}$ infection.

\section{CD4+ T helper responses (successful)}

Antigen-specific CD4+ $\mathrm{T}$ cells can recognise only cells expressing $\mathrm{MHC}$ Class II molecules-in other words professional antigen presenting cells or cells which have upregulated Class II as a result of inflammatory stimuli. Although, from first principles and from animal models such as LCMV it would be expected that CTL would play the most important role in controlling a pathogen that was replicating within hepatocytes, in fact there is considerable data supporting an important role for CD4+ $\mathrm{T}$ cell responses. Most striking of these is a genetic association between Class II genotype and spontaneous clearance of virus. Numerous studies have shown a link between possession of HLA DRB1*1101/DQ0301 (the two genes are in close linkage disequilibrium) and spontaneous viral control (these patients are recognised because they are HCV antibody positive but PCR negative). ${ }^{16}$ Additionally such patients possess stronger HCV specific CD4+ T cell responses than non DQ0301+ controls. ${ }^{17}$ As is the case for CTL, in acute disease strong and multispecific CD4+ $\mathrm{T}$ cell responses can be seen at the time of resolution of infection. ${ }^{18}$ Thus it is likely that early $\mathrm{T}$ helper responses play a significant role in determining the initial outcome of infection, although whether this is as direct effector cells or through maintenance of CTL responses is still unclear.

\section{Unsuccessful $\mathbf{T}$ cell responses}

Most patients fail to clear infection and here the picture becomes more confusing. Initial CTL and CD4+ $\mathrm{T}$ cell responses may still be observed ${ }^{18}$ and it remains to be determined what the differences between a successful and unsuccessful response are at this stage of infection. Once persistence is established an important difference becomes clear-ex vivo responses in chronically infected individuals are markedly attenuated. ${ }^{12,19}$ Possible reasons for this include viral variation and escape, $T$ cell compartmentalisation to the liver, ${ }^{19}$ and the use of assays which rely on function which underestimate cell frequencies. ${ }^{20}$ However, overall the frequencies of virus-specific CTL are much lower than during chronic infection with HIV. ${ }^{21}$ With careful screening techniques, a CTL response can be obtained in PBMC from about half the patients studied, ${ }^{22}$ and similar results have been obtained in liver derived lymphocytes. ${ }^{23}$ For CD4+ T helper responses it is relatively unusual to find strong and sustained responses in chronically infected individuals while this is common in spontaneous clearers. ${ }^{17}$ Treatment with interferon alpha has been shown to induce recovery of some $T$ helper responses, indicating that these $\mathrm{T}$ cells are not deleted completely. ${ }^{24}$

Paradoxically then, hepatic inflammation arises during persistent HCV infection where antigen specific $\mathrm{T}$ cells are usually weak or undetectable. There are two explanations for this. Firstly, levels of antigen specific $T$ cells might be higher in the liver than in blood. However, while this discrepancy may be about one order of magnitude, specific responses probably constitute only a minority of the infiltrate. ${ }^{25}$ Alternatively the large proportion of the infiltrate, which may be responsible for tissue damage, is non antigen specific. A similar situation has been observed in inflamed joints. ${ }^{26}$

\section{Mechanisms behind immunological failure}

A few potential mechanisms might explain both the relative lack of effectiveness of $\mathrm{T}$ cell responses overall (reflected in 
the capacity of the virus to persist) and the relative weakness of $\mathrm{T}$ cell responses seen in chronic infection.

\section{Viral variation}

Since HCV has a huge capacity for variation, generation of immune escape mutants is likely to play an important role in viral persistence. In chimpanzee models this has been very clearly shown-and appears to occur mainly during the initial months of infection. ${ }^{27}$ However, to date, the evidence from human studies has been relatively limited. ${ }^{28}$ Interestingly, studies of E2 protein in the putative region targeted by antibodies, has also shown evidence of immune mediated selection during acute infection. ${ }^{29}$

\section{T cell attenuation or modulation}

In murine models, at high viral loads of particular strains, $\mathrm{T}$ cells go through a process of exhaustion leading ultimately to clonal deletion. ${ }^{30,31}$ The mechanism behind this is not clear, but it is accelerated in the absence of functional CD4+ T cells, neutralising antibodies or cytokines such as interferons. ${ }^{32}$ Interestingly, in some situations, prior to deletion, a transient loss of the ability to secrete interferon gamma is observed ${ }^{33}$ a situation which has been also noted in HCV (stunned phenotype). ${ }^{12,14}$ Some have suggested that HCV derived proteins themselves may play a role in attenuating $\mathrm{T}$ cell responses. There is some in vivo evidence for an immuno- modulatory role for $\mathrm{HCV}$ core as expressed in a murine model. $^{34}$

Another potential explanation is that CTL may not achieve appropriate effector function, as has been suggested for HIV specific CTL. ${ }^{35}$ The phenotype of CTL identified in $\mathrm{HCV}$ is indeed distinct from that of CTL specific for EBV, HIV and CMV being high in CD27 and CD28 ${ }^{36}$ (Figure 1) although this may simply reflect their different lifespans, rather than skewed maturation. However, although these results are intriguing, it is too early to conclude anything about in vivo efficacy.

\section{The liver}

A variation on the theme of $T$ cell modulation is the liver effect. It is well known that the liver environment itself is a suitable one for promoting $\mathrm{T}$ cell tolerance. This evidence comes largely from early transplantation studies, ${ }^{37}$ where engraftment in certain species occurred across MHC barriers and where tolerance to other grafted organs may be generated. Important evidence from murine models suggests that there is an important role for the hepatocyte in antigen presentation and tolerance induction. Specific $\mathrm{T}$ cell proliferation of naive $\mathrm{T}$ cells, induced by hepatocytes, was comparable in magnitude to that seen in response to dendritic cells and was independent of CD4+ T cell help or bystander professional APC co-stimulation. However, thereafter, T cells exposed to hepatocytes underwent apoptosis. ${ }^{38}$

\section{Acute}

\section{Chronic}

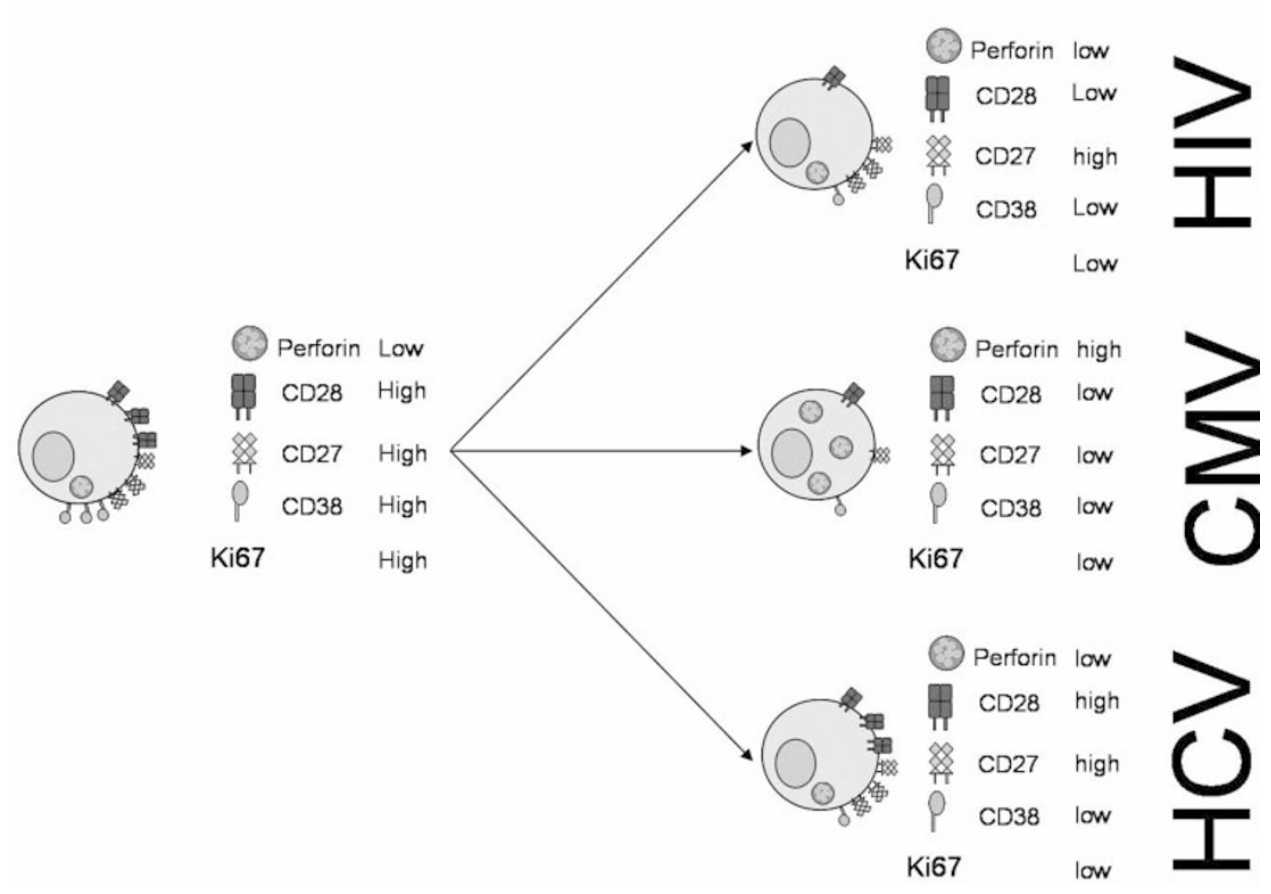

Figure 1 Comparison of CD8+ T cells surface markers in three different acute and chronic viral infections, HIV, CMV, and HCV. During the acute stage T cells show similar phenotypes, however this is not so during chronic stages of infection. CD28 is a co receptor for antigen induced stimulation. CD27 is a member of the TNF receptor family which is downregulated upon maturation of T cells. CD38 is a bifunctional surface enzyme, and is a marker associated with sustained activation of $\mathrm{T}$ cells 
Apoptosis of activated T cells is also seen following contact with hepatocytes. ${ }^{39}$

As yet the cellular and molecular basis of this tolerance induction is not fully understood. Part of it may arise from the particular anatomy of the liver, in which a rich blood supply (about a litre per $\mathrm{min}$ ) is greatly slowed in the capacious liver sinusoids. Here the lining cells (liver sinusoidal endothelial cells-LSECs), are thought to present a relatively loose barrier, having no basement membrane. It is possible that naive lymphocytes within the liver may contact hepatocytes directly-a situation which would be unique to the liver as naive $\mathrm{T}$ cells normally only recirculate to lymphoid tissue.

Additionally the slow transit time within the sinusoid is thought to allow ready contact with liver resident Kuppfer cells (liver macophages) and LSECs (Figure 2). It has been suggested that specific functions of Kuppfer cells, liver sinusoidal endothelial cells, as well as hepatocytes themselves may play a role in generating tolerance (via clonal deletion or induction of anergy). ${ }^{40}$ Teleologically, there may be important reasons for the liver to possess this capacity since many foreign antigens, which are absorbed through the gut, are present in this environment carried there by the hepatic portal vein. In the case of HCV infection, the virus may therefore have exploited this $\mathrm{T}$ cell downregulatory effect to establish persistence. Since the main target of HCV is the hepatocyte, we will now explore in detail the hepatocyte/T cell interaction, and address what the potential consequences are for both cell types and what the influence of the virus might be.

\section{Hepatocyte $-T$ cell interactions}

Virally infected hepatocytes will at some point during the infection interact with $T$ cells via a number of different surface molecules, several of which have the potential to affect $T$ cell activation.

\section{MHC class I}

Like all nucleated cells within the body hepatocytes express these human leukocyte antigens (HLAs). Their expression, which is generally low on hepatocytes, can be increaed in the presence of IFN- $\gamma$ and IFN- $\alpha .{ }^{41}$ A number of stealth viruses such as CMV are able to interfere with antigen presentation and thus hide from T-cell surveillance. ${ }^{42}$ So far only one report has looked at antigen presentation on cell lines expressing HCV proteins showing that there is no impairment. ${ }^{43}$

\section{Other aspects of hepatocyte surface phenotype}

One of the restrictions facing the study of hepatocytes is the difficulty of working with normal primary hepatocytes. Acquiring, isolating, and growing primary hepatocytes are all difficult and cultures only last short term. Hepatocellular carcinoma lines (e.g. HepG2 and Huh7) present a more convenient model due to the ease by which they can be grown. However, like all tumours, hepatocellular carcinoma lines have undergone transformation and possibly have an altered surface phenotype. Table 1 summarises the current

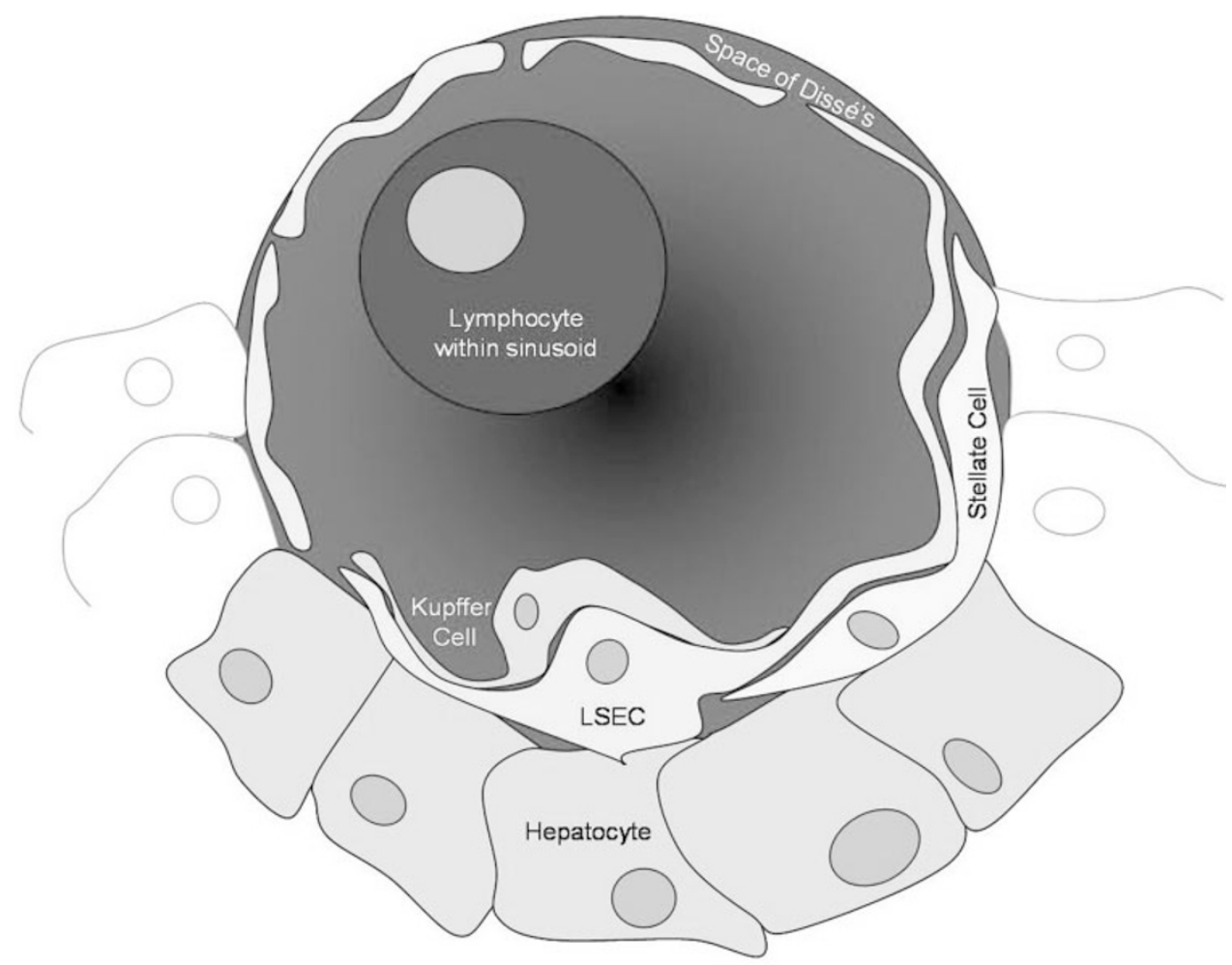

Figure 2 Cartoon of the liver sinusoidal micro-environment. T cell access to hepatocytes could occur via fenestrations in the liver sinusoidal epithelial cells (LSEC). Interactions with LSEC may also be important 
Table 1 Comparison of surface molecules between primary hepatocytes and hepatocarimona lines

\begin{tabular}{|c|c|c|c|c|}
\hline & & & Normal & \\
\hline & HepG2 & Huh7 & hepatocytes & References \\
\hline MHC class I & $\checkmark$ & $\checkmark$ & $\checkmark$ & $61-64$ \\
\hline MHC class II & $\boldsymbol{x}$ & $\boldsymbol{x}$ & $\begin{array}{c}\boldsymbol{V} / \boldsymbol{x} \\
\text { (mixed } \\
\text { reports) }\end{array}$ & 61,65 \\
\hline ICAM-1 (CD54) & $\nu$ & $?$ & $\checkmark$ & $61,66,67$ \\
\hline LFA-3 (CD58) & $\checkmark$ & $?$ & $\nu$ & 61 \\
\hline EGF receptor & $\nu$ & $\nu$ & $\nu$ & 61 \\
\hline $\begin{array}{l}\text { Fas/Apo-1 } \\
\text { (CD95) }\end{array}$ & $\checkmark$ & $\nu$ & $\nu$ & $61,68,69$ \\
\hline FASL (CD95L) & $\checkmark$ & $\mathbf{x}$ & $\nu^{*}$ & $47,61,70,71$ \\
\hline CD40 & $\begin{array}{c}\boldsymbol{*} / \boldsymbol{v} \\
\text { (mixed } \\
\text { reports) }\end{array}$ & $?$ & $\nu$ & 61,72 \\
\hline CD44 & $\mathbf{x}$ & $?$ & $\checkmark$ & $61,73,74$ \\
\hline CD81 & $\boldsymbol{x}$ & $?$ & $\checkmark$ & 75 \\
\hline CD1d & $?$ & $?$ & $\checkmark$ & 76 \\
\hline DR4 & $?$ & $\nu$ & $?$ & 77 \\
\hline DR5 & $?$ & $\nu$ & $?$ & 77 \\
\hline CD80 & $?$ & $?$ & $\nu^{*}$ & 47,78 \\
\hline CD86 & $?$ & $?$ & $\boldsymbol{\nu}^{*}$ & 78 \\
\hline
\end{tabular}

*Upregulated in chronic hepatitis

known phenotype for HepG2 and Huh7 hepatoma lines, and primary hepatocytes.

\section{Functional consequences of hepatocyte-T cell interactions}

Perforin and granzyme induced cell death is an important mechanism in the clearance of infected cells by CTLs. However, hepatocytes in mice have been shown to be relatively poorly susceptible to perforin-dependent pathways. ${ }^{44}$ Perforin-independent IFN- $\gamma$-dependent mechanisms within the liver are thought to be particularly important ${ }^{45}$ in antiviral control. Nevertheless perforin deficient mice still fail to clear non-cytopathic LCMV from the liver, ${ }^{46}$ although potentially Kuppfer cells rather than hepatocytes still harbour virus in this case. ${ }^{45}$

Both human and murine primary hepatocytes have been shown to be sensitive to CD95L induced apoptosis. Fas has been shown to be more frequently up-regulated in HCV patients on hepatocytes surrounding CTL infiltrates. ${ }^{47}$ FasFasL interaction may also be involved in bystander killing accounting for some of the pathology seen during HCV infections. ${ }^{48}$ Normal healthy hepatocytes do not express FasL. However, Galle et al. ${ }^{49}$ showed that FasL mRNA was expressed in hepatocytes from livers with ongoing damage and in livers with Hepatitis B virus infection FasL expression was seen in areas of lymphocyte infiltration, potentially leading to killing of the antiviral T-cells.

\section{Cytokines and chemokines}

T cells within the liver, as elsewhere, will be responsive to a variety of cytokines, but much less is known about the effects of such cytokines on hepatocytes, particularly the effects that might influence hepatocyte-T cell interactions.
Table 2 Cytokines potentially present during HCV infection and their effects on hepatocytes

\begin{tabular}{ll}
\hline & Hepatocytes \\
\hline IFN- $\gamma$ & - Increased expression of MHC class I and \\
& ICAM-1 (CD54) \\
& - In primary hepatocytes p53 is induced followed by cell \\
& cycle arrest and apoptosis (independent of p53) \\
& - Proliferation \\
TNF- $\alpha$ & - Apoptosis under hepatotoxic conditions \\
& - Increased MHC class I surface expression and \\
& ICAM-1 \\
& - Induction of interleukin-1 receptor antagonists \\
& - Up-regulation of Cytochrome P4502E1 (CYP2E1) \\
IL-4 & - Up-regulation of acute phase proteins \\
& - Inhibition of antiviral action by IFN- $\alpha$ by inducing $^{86}$ \\
IL-6 & SOCS2, SOCS3, and CIS expression ${ }^{51}$ \\
IL-10 & Production of chemokines, monokine induced by \\
& IFN- $\gamma$ (MIG) and inducible protein 10, (IP-10) ${ }^{87}$ \\
IL-12 &
\end{tabular}

While many of the cytokines may be derived from $\mathrm{T}$ cells and resident Kuppfer cells. It has been suggested that hepatocytes themselves may also make cytokines. ${ }^{50}$

The responses of hepatocytes to cytokines are outlined in Table 2. With regards to the Th1 type cytokines (IFN- $\gamma$ and $\mathrm{IL}-12$ ) their effects overall appear to be to improve the ability of the hepatocytes to present antigen, to promote influx of activated lymphocytes through chemokine secretion, and to prime hepatocytes for death through apoptosis. Much less is known about a Th2 type cytokine effect on the liver. Interestingly IL-10 appears to inhibit the action of the antiviral cytokine IFN- $\alpha^{51}$

Hepatocyte derived chemokines, notably monokine induced by IFN- $\gamma$ (MIG) and IFN- $\gamma$ induced protein 10 (IP$10)$, which have been shown to play a role in murine models of HBV and are elevated in chronic HCV are likely to be important in regulating lymphocyte recruitment to $\mathrm{HCV}$ infected livers. ${ }^{52-54}$

\section{Hypothesis - two competing loops for lymphocytes}

In acute infection with $\mathrm{HCV}$, antigen presentation is likely to occur in two environments - the liver and within lymph nodes. Antigen will be presented in lymph nodes either through cross-presentation or via presentation on infected dendritic cells. ${ }^{55}$ Expansion of virus specific T cell clones accompanied by activation and expression of appropriate homing and chemokine receptors will provide a set of virus specific $T$ cells ready for their maiden voyage into the liver (maiden $T$ cells). We currently lack evidence that this phase of the immune response is impaired, since virus-specific $T$ cells can be readily detected during acute infection, ${ }^{12,13}$ although they do take several weeks to emerge. ${ }^{14}$

$T$ cells, both naive and maiden (i.e. on their first voyage into the liver) which enter the liver during acute infection will contact infected hepatocytes bearing peptide MHC complexes on their cell surface, as well as LSECs and Kupffer cells. We hypothesize that at this point, the cellular and molecular features outlined above lead to downregulation of $T$ cell function and attenuation of the functional response. At the same time, effector functions of these $T$ cells will 
lead to downregulation of virus replication through secretion of antiviral cytokines, and apoptosis and death of the infected cells, and potentially bystander cells. ${ }^{39}$

The outcome of this process will depend on the dynamics involved. If cross-presentation is relatively inefficient, as has been suggested, ${ }^{56} \mathrm{~T}$ cell responses will emerge relatively late, at a time point when a substantial number of hepatocytes are infected. (There are $10^{8}$ hepatocytes per gram of liver tissue and approximately 1500 grams of liver in an average human, thus $1.5 \times 10^{11}$ total hepatocytes). The rate of elimination of virus infected cells may thus be slower than the rate of infection of new hepatocytes and so persistence will ensue.

Beyond the simple dynamics, the other key factor determining outcome is the relative efficiency of control of viral replication. Immune responses to hepatitis B virus are subject to the same basic constraints, with late generation of $T$ cell responses in the face of a very large number of infected hepatocytes-yet in adults this virus is largely controlled. A number of factors might explain the difference-the capacity to generate viral variants, the inability to generate neutralising antibodies, and-potentially-differential sensitivity to antiviral cytokines. Many of these factors may compound each other-thus attenuation of $\mathrm{T}$ cell responses at the surface of the hepatocyte might lead to maintenance of high viral loads and therefore promote immune escape. Further persistence might then lead to downregulation of CD4+ $\mathrm{T}$ cell responses and therefore impairment of CTL responses. ${ }^{57}$

\section{Two loop theory}

We have proposed the two loop theory, whereby presentation of $\mathrm{HCV}$ antigens within the liver environment promotes attenuation of $\mathrm{T}$ cell responses (or $\mathrm{T}$ cell dysfunction) and viral persistence, while simultaneously presentation in lymphoid organs promotes effective $\mathrm{T}$ cell responses and control of viremia. ${ }^{58}$ During persistence the negative loop is dominant, and in resolved disease the positive loop dominant. This pattern is seen in both chronic HBV and HCV infection and differs markedly from other viruses, which are less strictly hepatotopic (EBV, CMV and HIV) and where relatively strong $\mathrm{T}$ cell responses are maintained (Figure 3).

This theory helps to explain the conundrum of apparently weak $T$ cell responses but persistent intrahepatic inflammation. Since T cells are continuously activated, they will transit through the blood and enter the liver, where they receive signals leading to death or downregulation of function. ${ }^{39} \mathrm{At}$ the hepatocyte surface, they can induce apoptosis of target cells and secrete inflammatory cytokines, but then will be

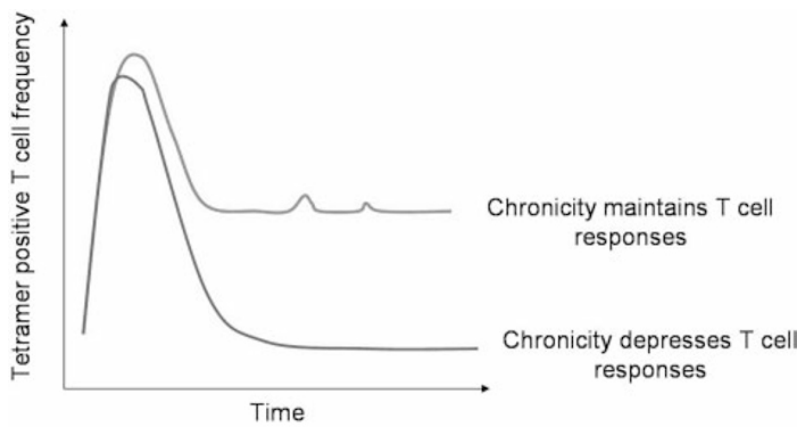

Figure 3 Patterns of virus specific T cells found in blood in different types of persisting viral infections. Red indicates the tetramer positive $T$ cell response (frequency) to EBV or CMV or HIV. The blue line indicates tetramer positive responses to chronic HCV or HBV. Acutely, a response of $1-10 \%$ of CD8 T cells per epitope would be typical, although these may occasionally be much higher in EBV. In the chronic phase a response of $<0.1 \%$ of CD8+ T cells would be typical for chronic HBV and HCV, while responses of $1-10 \%$ may be sustained in the other infections
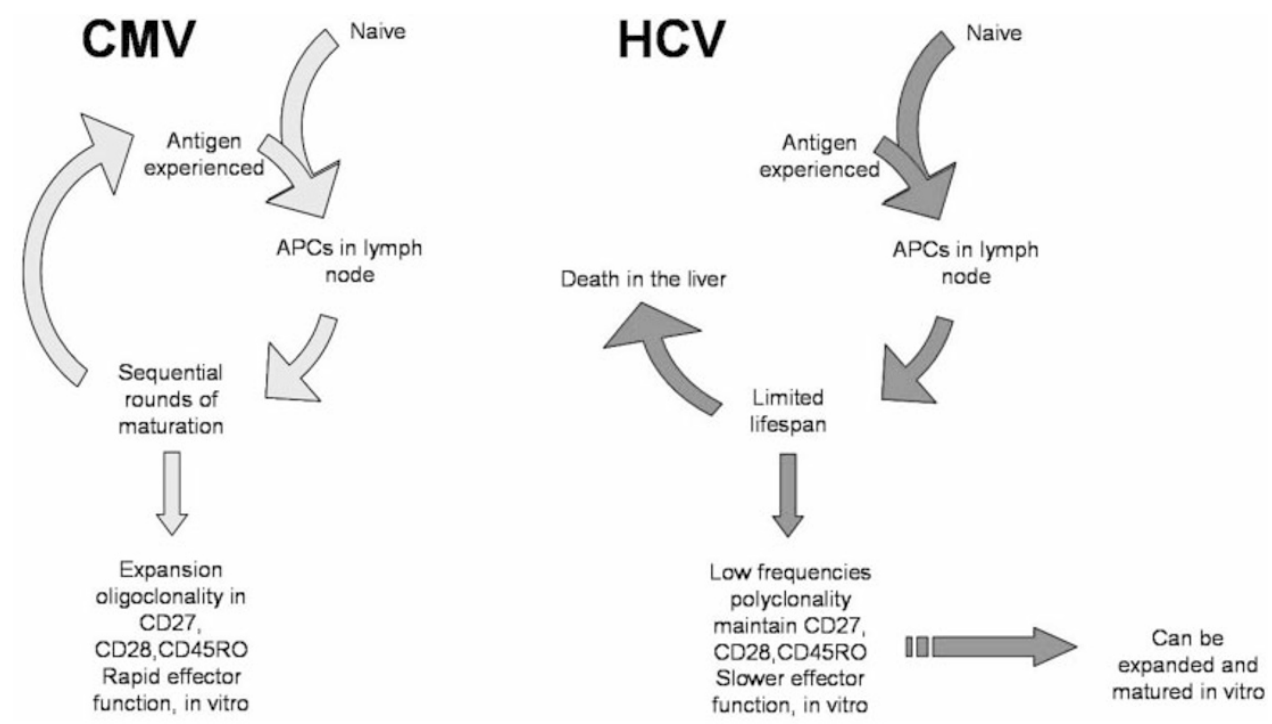

Figure 4 Hypothesis: Death and the maiden T cell. CTL specific for CMV go through multiple rounds of reactivation over time leading to a mature or effector phenotype. Although death may occur in the liver, since little CMV antigen is presented there the effect is not significant overall. In contrast, HCV specific populations will undergo death when they encounter antigen in the liver and not go through multiple rounds of restimulation in vivo. This explains the lower frequency in blood, immature phenotype, and weaker effector activity * but their intact ability to proliferate in response to antigen in vitro 
eliminated. Thus, overall, fairly low numbers of $\mathrm{T}$ cells will be maintained, even though the generation of such cells may remain intact. If this equilibrium is disturbed-e.g. through treatment - a reduction in the death of cells within the liver will lead to an apparent re-emergence of previously undetectable immune responses.

This theory also helps explain an apparent discrepancy in the literature. Early papers, which used in vitro restimulation protocols to detect CTL, often described multispecific responses in chronically infected patients, ${ }^{59,60}$ while current ex vivo assessments often find very low $T$ cell numbers. ${ }^{12}$ If CTLs are indeed present but the frequency is low due to liver-mediated downregulation, they may easily be missed ex vivo, since such tests may pick up about $0.02 \%$ of CD8+ T cells. However, rapid expansion in vivo is readily demonstrated ${ }^{22}$ indicating that such cells do exist and that they have the capacity to respond to antigen. In vitro restimulation simply accentuates the positive loop and eliminates the negative loop.

Finally, this theory helps explain the distinctive phenotype of $\mathrm{HCV}$ specific CTL. Sequential encounters with antigen will lead to a phenotype which is low in CD28, CD27, CD45RO, high in perforin and shows rapid IFN- $\gamma$ secretion, as exemplified by CMV. HCV specific CTL are at the opposite end of this spectrum. One simple reason may be that they do not undergo multiple rounds of antigen restimulation, but rather die in the liver before expansion and maturation can occur. Thus the phenotype does not represent 'skewing' but merely 'inexperience' of the $T$ cell population (see Figure 4).

If this is the case, in vivo immune modulation to promote the $\mathrm{T}$ cell responses and aid resolution of chronic infection could potentially be successful-as long as the negative loop is at least temporarily reduced. Similarly $\mathrm{T}$ cell vaccines, which accelerate the initiation of and maintenance of the positive loop, may also be approached with some confidence.

\section{Conclusions}

Although a reasonable amount of information is available concerning circulating $\mathrm{HCV}$ specific $\mathrm{T}$ cells at various stages of disease, we are still very much in the dark about the important events that occur at the surface of an infected hepatocyte. We have reviewed the data on the phenotype and immunological function of hepatocytes, but it is clearly limited. More in vitro data is required using non transformed human cells and other liver derived cells such as LSECs. Also, more in vivo data is needed in model situations which are relevant to human chronic viral infections. This is an important area, both in terms of normal immunobiology and pathology. Until we understand it at a molecular level, watching $T$ cell populations wax and wane in infected patients will remain a mysterious dark art.

\section{Acknowledgements}

This work was supported by the BBSRC (C Willberg), the Medical Research Council (E Barnes), the Wellcome Trust and the European Union-grant code QLK2-CT-1999-00356 (P Klenerman).

\section{References}

1. Cohen J (1999) The scientific challenge of hepatitis C. Science 285: 26-30

2. Frank C, Mohamed MK, Strickland GT, Lavanchy D, Arthur RR, Magder LS, El Khoby T, Abdel-Wahab, Y, Aly OhnES, Anwar W and Sallam I. (2000) The role of parenteral antischistosomal therapy in the spread of hepatitis $C$ virus in Egypt. Lancet 355: $887-891$

3. Lauer GM and WalkerBD (2001) Hepatitis C virus infection. N. Engl. J. Med. 345: 41-52

4. Klenerman $P$, Lucas $M$, Barnes $E$ and Harcourt $G$ (2002) Immunity to hepatitis $C$ virus: stunned but not defeated. Microbes Infect. 4: 57-65

5. VanderBroek M, Muller U, Hang S, Aguet M and Zinkernagel R (1995) Antiviral immunity in mice lacking both alpha/beta and gamma interferon receptors. J. Virol. 69: 4792-4796

6. Karrer U, Althage A, Odermatt B, Hengartner H and Zinkernagel RM (2000) Immunodeficiency of alymphoplasia mice (aly/aly) in vivo: structural defect of secondary lymphoid organs and functional B cell defect. Eur. J. Immunol. 30: 2799-2807

7. Planz O, Ehl S, Furrer E, Horvath E, Brundler M, Hengartner Hand Zinkernagel R (1997) A critical role for neutralising antibody-producing B cells, CD4+ cells and interferons in persistent infections of mice with LCMV: implications for adoptive immunotherapy of virus carriers. Proc. Natl. Acad. Sci USA 94: 6874-6879

8. Ciurea A, Klenerman P, Hunziker L, Horvath E, Senn BM, Ochsenbein AF, Hengartner $\mathrm{H}$ and Zinkernagel RM. (2000) Viral persistence in vivo through selection of neutralizing antibody-escape variants. Proc. Natl. Acad. Sci. USA 97: $2749-2754$

9. Zajac AJ, Blattman JN, Murali-Krishna K, Sourdive DJ, Suresh M, Altman JD and Ahmed R (1998) Viral immune evasion due to persistence of activated T cells without effector function. J. Exp. Med. 188: 2205-2213

10. Zajac A, Blattman J, Murali-Krishna K, Sourdive D, Suresh M, Altman J and Ahmed R (1998) Viral immune evasion due to persistence of activated T cells without effector function. J. Exp. Med. 188: 2205-2213

11. Klenerman $P$, Cerundolo $V$ and Dunbar $R$ (2002) Tracking T cells with tetramers: New Tales from new tools. Nature Rev. 2: 263-271

12. Lechner F, Wong DK, Dunbar PR, Chapman R, Chung RT, Dohrenwend P, Robbins G, Phillips R, Klenerman P and Walker BD. (2000) Analysis of successful immune responses in persons infected with hepatitis $C$ virus. J. Exp. Med. 191: 1499-1512

13. Lechner F, Gruener N, Urbani S, Uggeri J, Santantonio T, Cerny A, Phillips R, Ferrari C, Pape G and Klenerman P. (2000) CTL responses are induced during acute HCV infection but are not sustained. Eur. J. Immunol. 30: 2479-2487

14. Thimme R, Oldach D, Chang KM, Steiger C, Ray SC and Chisari FV (2001) Determinants of viral clearance and persistence during acute hepatitis $C$ virus infection. J. Exp. Med. 194: 1395-1406

15. Cooper S, Erickson A, Adams E, Kansopon J, Weiner A, Chien D, Houghton M, Parham P and Walker C. (1999) Analysis of a successful immune response against HCV. Immunity 10: 439-449

16. Thursz M, Yallop R, Goldin R, Trepo C, Thomas HC (1999) Influence of MHC class II genotype on outcome of infection with hepatitis $C$ virus. The HENCORE group. Hepatitis C European Network for Cooperative Research. Lancet 354: 2119-2124

17. Harcourt G, Hellier S, Bunce M, Satsangi J, Collier J, Chapman R, Phillips R and Klenerman P. (2001) Effect of HLA Class II genptype on T helper lymphocyte responses and viral control in HCV infection. J. Viral. Hepat. 8: 174-179

18. Gerlach J, Diepolder H, Jung M-C, Gruener N, Schraut W, Zachoval R, Hoffman R, Schirren C, Santantonio T and Pape G. (1999) Recurrence of HCV after loss of virus specific CD4+ T cell response in acute Hepatitis C. Gastroenterology 117: $933-941$

19. He X-S, Rehermann B, Lopez-Labrador F, Boisvert J, Cheung R, Mumm J Wedermeyer H, Berenguer M, Wright T and Davis M. (1999) Quantitative analysis of HCV-specific CD8+T cells in peripheral blood and liver using peptideMHC tetramers. Proc. Natl. Acad. Sci. USA 96: 5692-5697

20. Gruener N, Lechner F, Jung M-C, Diepolder H, Gerlach T, Lauer G, Walker B, Sullivan J, Phillips Rand Pape G. (2001) Sustained dysfunction of antiviral CD8+ T lymphocytes after infection with HCV. J. Virol. 75: 5550-5558 
21. Lauer GM, Nguyen TN, Day CL, Robbins GK, Flynn T, McGowan K, Rosenberg ES, Lucas M, Klenerman P, Chung RT and Walker BD. (2002) Human immunodeficiency virus type 1-hepatitis $C$ virus coinfection: intraindividua comparison of cellularimmune responses against two persistent viruses. J. Virol. 76: $2817-2826$

22. Lauer G, OuchiK, Chung R, Nguyen T, Day C, Purkis D, Reiser M, Kim AY, Lucas $\mathrm{M}$, Klenerman $\mathrm{P}$ and Walker BD. (2002) Comprehensive analysis of CD8+ T-cell responses against $\mathrm{HCV}$ reveals multiple unpredicted specificities. J. Virol. 76: 6104-6113

23. Wong DK, Dudley DD, Afdhal NH, Dienstag J, Rice CM, Wang L, Houghton M WalkerBD and Koziel MJ. (1998) Liver-derived CTL in hepatitis C virus infection: breadth and specificity of responses in a cohort of persons with chronic infection. J. Immunol. 160: 1479-1488

24. Cramp ME, Rossol S, Chokshi S, Carucci P, Williams Rand Naoumov NV (2000) Hepatitis C virus-specific T-cell reactivity during interferon and ribavirin treatment in chronic hepatitis C. Gastroenterology 118: 346-355

25. Grabowska AM, Lechner F, Klenerman P, Tighe PJ, Ryder S, Ball JK, Thomson BJ, Irving WL and Robins RA. (2001) Direct ex vivo comparison of the breadth and specificity of the T cells in the liver and peripheral blood of patients with chronic HCV infection. Eur. J. Immunol. 31: 2388-2394

26. Scotet E, Peyrat MA, Saulquin X, Retiere C, Couedel C, Davodeau F, Dulphy N Toubert A, Bignon JD, Lim A, Vie H, Hallet MM, Liblau R, Weber M, Berthelot JM Houssaint E, Bonneville M. (1999) Frequent enrichment for CD8 T cells reactive against common herpes viruses in chronic inflammatory lesions: towards a reassessment of the physiopathological significance of $T$ cell clonal expansions found in autoimmune inflammatory processes. Eur. J. Immunol. 29: 973-985

27. Weiner D, Erickson A, Kansopon J, Crawford K, Muchmore E, Hughes A Houghton Mand WalkerC. (1995) Persistent Hepatitis C infection in a chimpanze is associated with emergence of a CTL escape variant. Proc. Nat. Acad. Sci. USA 82: $2755-2759$

28. Chang K, Rehermann B, McHutchinson J, Pasquellini C, Southwood S, Sette A and Chisari F (1997) Immunological significance of CTL epitope variants in patients chronically infected by HCV. J. Clin. Invest. 100: 2376-2385

29. Farci P, Shimoda A, Coiana A, Diaz G, Peddis G, Melpolder JC, Strazzera A Chien DY, Munoz SJ, Balestrieri A, Purcell RH and Alter HJ. (2000) The outcome of acute hepatitis $C$ predicted by the evolution of the viral quasispecies. Science 288: $339-344$

30. Moskophidis D, Lechner F, Pircher H and Zinkernagel RM. (1993) Virus persistence in acutely infected immunocompetent mice by exhaustion of antivira cytotoxic effector T cells. Nature 362: 758-761

31. Gallimore A, Glitheroe A, Godkin A, Tissot A, Hengartner H, Elliott $T$ and Zinkernagel R (1998) Induction and exhaustion of LCMV-specific CTL visualised using soluble tetrameric MHC-peptide complexes. J. Exp. Med. 187: 13831393

32. Battegay M, Moskophidis D, Rahemtulla A, Hengartner H, Mak TW and Zinkernagel RM. (1994) Enhanced establishment of a virus carrier state in adult CD4+ T-cell-deficient mice. J. Virol. 68: 4700-4704

33. Ou R, Zhou S, Huang L and Moskophidis D (2001) Critical role for alpha/beta and gamma interferons in persistence of lymphocytic choriomeningitis virus by clonal exhaustion of cytotoxic T cells. J. Virol. 75: 8407-8423

34. Large MK, Kittlesen DJ and Hahn YS (1999) Suppression of host immune response by the core protein of hepatitis $C$ virus: possible implications for hepatitis $C$ virus persistence. J. Immunol. 162: 931-938

35. Appay V, Nixon DF, Donahoe SM, Gillespie GM, Dong T, King A, Ogg GS, Spiegel HM, Conlon C, Spina CA, Havlir DV, Richman DD, Waters A Easterbrook P, McMichael AJ and Rowland-Jones SL. (2000) HIV-specific CD8(+) T cells produce antiviral cytokines but are impaired in cytolytic function. J. Exp. Med. 192: 63-75

36. Appay V, Dunbar R, Callan M, Klenerman P, Gillespie GMA, Papagno L, Ogg GS King A, Lechner F, Spina CA, Little S, Havlir DV, Richman DD, Gruener N, Pape G, Waters A, Easterbrook P, Salio M, Cerundolo V, McMichael AJ and RowlandJones SL. (2002) Memory CD8+ T cells vary in differentiation phenotype in different persistent virus infections. Nature Med. 8: 379-385

37. Calne RY, Sells RA, Pena JR, Davis DR, Millard PR, Herbertson BM, Binns RM and Davies DA. (1969) Induction of immunological tolerance by porcine liver allografts. Nature 223: $472-476$

38. Bertolino P, Trescol-Biemont MC and Rabourdin-Combe C. (1998) Hepatocytes induce functional activation of naive CD8+ T lymphocytes but fail to promote survival. Eur. J. Immunol. 28: 221-236
39. Mehal WZ, Azzaroli F and Crispe IN (2001) Antigen presentation by liver cells controls intrahepatic $T$ cell trapping, whereas bone marrow-derived cells preferentially promote intrahepatic T cell apoptosis. J. Immunol. 167: 667-673

40. Knolle PA and Gerken G (2000) Local control of the immune response in the liver. Immunol. Rev. 174: 21-34

41. Schroder AJ, Blaheta RA, Scholz M, Kronenberger B, Encke A and Markus BH (1995) Effects of proinflammatory cytokines on cultivated primary human hepatocytes. Fluorometric measurement of intercellular adhesion molecule-1 and human leukocyte antigen-A, -B, -C, and-DR expression. Transplantation 59: 1023-1028

42. Beersma MF, Bijlmakers MJ and Ploegh HL (1993) Human cytomegalovirus down-regulates HLA class I expression by reducing the stability of class I H chains. J. Immunol. 151: $4455-4464$

43. Moradpour D, Grabscheid B, Kammer AR, Schmidtke G, Groettrup M, Blum HE and Cerny $A$ (2001) Expression of hepatitis $C$ virus proteins does not interfere with major histocompatibility complex class I processing and presentation in vitro. Hepatology 33: $1282-1287$

44. Kafrouni MI, Brown GR and Thiele DL (2001) Virally infected hepatocytes are resistant to perforin-dependent CTL effector mechanisms. J. Immunol. 167: 1566- 1574

45. Guidotti LG, Rochford R, Chung J, Shapiro M, Purcell R and Chisari FV (1999) Viral clearance without destruction of infected cells during acute HBV infection. Science 284: 825-829

46. Kagi D, Seiler P, Pavlovic J, Ledermann B, Burki K, Zinkernagel RM and Hengartner $\mathrm{H}$ (1995) The roles of perforin- and Fas-dependent cytotoxicity in protection against cytopathic and noncytopathic viruses. Eur. J. Immunol. 25: $3256-3262$

47. Fiore G, Piazzolla G, Galetta V, Caccetta L, Schiraldi O and Antonaci S (1999) Liver tissue expression of CD80 and CD95 antigens in chronic hepatitis C: relationship with biological and histological disease activities. Microbioscience 97: $29-38$

48. Ando K, Hiroishi K, Kaneko T, Moriyama T, Muto Y, Kayagaki N, Yagita $H$, Okumura K and Imawari M. (1997) Perforin, Fas/Fas ligand, and TNF-alpha pathways as specific and bystander killing mechanisms of hepatitis $C$ virusspecific human CTL. J. Immunol. 158: 5283-5291

49. Galle PR, Hofmann WJ, Walczak H, Schaller H, Otto G, Stremmel W, Krammer $\mathrm{PH}$ and Runkel L. (1995) Involvement of the CD95 (APO-1/Fas) receptor and ligand in liver damage. J. Exp. Med. 182: 1223-1230

50. Stonans I, Stonane E, Russwurm S, Deigner HP, Bohm KJ, Wiederhold M, Jager L and Reinhart K. (1999) HepG2 human hepatoma cells express multiple cytokine genes. Cytokine 11: 151-156

51. Shen X, Hong F, Nguyen VA and Gao B (2000) IL-10 attenuates IFN-alphaactivated STAT1 in the liver: involvement of SOCS2 and SOCS3. FEBS Lett. 480: $132-136$

52. Narumi S, Tominaga $Y$, Tamaru M, Shimai S, Okumura H, Nishioji K, Itoh $Y$ and Okanoue T. (1997) Expression of IFN-inducible protein-10 in chronic hepatitis. J. Immunol. 158: 5536-5544

53. Nishioji K, Okanoue T, Itoh Y, Narumi S, Sakamoto M, Nakamura H, Morita A and Kashima K. (2001) Increase of chemokine interferon-inducible protein-10 (IP-10) in the serum of patients with autoimmune liver diseases and increase of its $\mathrm{mRNA}$ expression in hepatocytes. Clin. Exp. Immunol. 123: 271-279

54. Kakimi K, Lane TE, Wieland S, Asensio VC, Campbell IL, Chisari FV and Guidotti LG (2001) Blocking chemokine responsive to gamma-2/interferon (IFN)-gamma inducible protein and monokine induced by IFN-gamma activity in vivo reduces the pathogenetic but not the antiviral potential of hepatitis B virus-specific cytotoxic T lymphocytes. J. Exp. Med. 194: 1755-1766

55. Bain C, Fatmi A, Zoulim F, Zarski JP, Trepo C and Inchauspe G (2001) Impaired allostimulatory function of dendritic cells in chronic hepatitis $C$ infection. Gastroenterology 120: 512-524

56. Ochsenbein AF, Sierro S, OdermattB, Pericin M, KarrerU, Hermans J, Hemmi S, Hengartner $\mathrm{H}$ and Zinkernagel RM. (2001) Roles of tumour localization, second signals and cross priming in cytotoxic T-cell induction. Nature 411: 1058-1064

57. Klenerman $P$, Lechner F, Kantzanou M, Ciurea A, Hengartner Hand Zinkernagel $R$ (2000) Viral escape and the failure of cellular immune responses. Science 289 : 2003

58. Ward S, Lauer G, Isba R, Walker B and Klenerman P (2002) Cellular immune responses againsthepatitis $C$ virus: the evidence base 2002. Clin. Exp. Immunol. 128: 195-203 
59. Cerny A, Fowler P, Brothers M, Houghton M, Schlicht $H$ and Chisari $F$ (1995) Induction in vitro of a primary human antiviral cytotoxic $\mathrm{T}$ cell response. Eur. J. Immnuol. 25: 627-630

60. Rehermann B, Chang K, McHutchinson J, Kokka R, Houghton M and Chisari F (1996) Quantitative analysis of the peripheral blood CTL response in patients with chronic HCV infection. J. Clin. Invest. 98: 1432-1440

61. Cruickshank SM, Southgate J, Selby PJ and Trejdosiewicz LK (1998) Expression and cytokine regulation of immune recognition elements by normal human biliary epithelial and established liver cell lines in vitro. J. Hepatol. 29: $550-558$

62. Wang D, Yang E and Cheng LY (1997) Effects of IFN-gamma, TNF-alpha and EGF on the expression of HLA class I antigen and the proliferation of human hepatocellular carcinoma HepG2 cells. Anticancer Res. 17: 181-188

63. Paroli M, Carloni G, Franco A, De Petrillo G, Alfani E and Barnaba V (1993) Human hepatoma cells expressing HLA class I molecules stimulate primary responses of purified CD8+ T lymphocytes. Res. Virol. 144: 327-332

64. Paroli M, Carloni G, Franco A, De Petrillo G, Alfani E, Perrone A and Barnaba V (1994) Human hepatoma cells expressing MHC antigens display accessory cell function: dependence on LFA-1/ICAM-1 interaction. Immunology 82: 215-221

65. Ren EC, Wong LY and Chan SH (1988) Effect of recombinant gamma interferon on hepatocellular carcinoma cell lines. Cancer Lett. 39: 305-310

66. Mickelson JK, Kukielka G, Bravenec JS, Mainolfi E, Rothlein R, Hawkins HK Kelly JH and Smith CW. (1995) Differential expression and release of CD54 induced by cytokines. Hepatology 22: 866-875

67. Gulubova MV (1998) Intercellular adhesion molecule-1 (ICAM-1) expression in the liver of patients with extrahepatic cholestasis. Acta Histochem. 100: 59-74

68. Desbarats $\mathrm{J}$ and Newell MK (2000) Fas engagement accelerates liver regeneration after partial hepatectomy. Nat. Med. 6: 920-923

69. Lamboley C, Bringuier AF and Feldmann G (2000) Apoptotic behaviour of hepatic and extra-hepatic tumor cell lines differs after Fas stimulation. Cell. Mol. Biol. (Noisy-le-grand) 46: 13-28

70. Roskams T, Libbrecht L, Van DammeB and Desmet V (2000) Fas and Fas ligand: strong co-expression in human hepatocytes surrounding hepatocellular carcinoma; can cancer induce suicide in peritumoural cells? J. Pathol. 191: $150-153$

71. Muller M, Strand S, Hug H, Heinemann EM, Walczak H, Hofmann WJ, Stremmel W, Krammer PH and Galle PR. (1997) Drug-induced apoptosis in hepatoma cells is mediated by the CD95 (APO-1/Fas) receptor/ligand system and involves activation of wild-type p53. J. Clin. Invest. 99: 403-413

72. Afford SC, Randhawa S, Eliopoulos AG, Hubscher SG, Young LS and Adams DH (1999) CD40 activation induces apoptosis in cultured human hepatocytes via induction of cell surface fas ligand expression and amplifies fas-mediated hepatocyte death during allograft rejection. J. Exp. Med. 189: 441-446

73. Satoh T, Ichida T, Matsuda Y, Sugiyama M, Yonekura K, Ishikawa T and Asakura $H(2000)$ Interaction between hyaluronan and CD44 in the development of dimethylnitrosamine-induced liver cirrhosis. J. Gastroenterol. Hepatol. 15:402411

74. Mathew J, Hines JE, Obafunwa JO, Burr AW, Toole Kand Burt AD (1996) CD44 is expressed in hepatocellular carcinomas showing vascular invasion. J. Pathol. 179: $74-79$
75. Kronenberger B, Ruster B, Elez R, Weber S, Piiper A, Lee JH, Roth WK and Zeuzem S. (2001) Interferon alfa down-regulates CD81 in patients with chronic hepatitis C. Hepatology 33: 1518-1526

76. Trobonjaca Z, Leithauser F, Moller P, Schirmbeck R and Reimann J (2001) Activating immunity in the liver. I. Liver dendritic cells (but not hepatocytes) are potent activators of IFN-gamma release by liver NKT cells. J. Immunol. 167 1413-1422

77. Higuchi H, Bronk SF, Takikawa Y, Werneburg N, Takimoto R, El-Deiry W and Gores GJ (2001) The bile acid glycochenodeoxycholate induces trail-receptor 2/ DR5 expression and apoptosis. J. Biol. Chem. 276: 38610-38618

78. Mochizuki K, Hayashi N, Katayama K, Hiramatsu N, Kanto T, Mita E, Tatsumi T, Kuzushita N, Kasahara A, Fusamoto H, Yokochi T, Kamada T. (1997) B7/BB-1 expression and hepatitis activity in liver tissues of patients with chronic hepatitis C. Hepatology 25: 713-718

79. Kano A, Watanabe Y, Takeda N, Aizawa S and Akaike T. (1997) Analysis of IFNgamma-induced cell cycle arrest and cell death in hepatocytes. J. Biochem. (Tokyo) 121: 677-683

80. Beyer HS and Stanley M (1990) Tumor necrosis factor-alpha increases hepatic DNA and RNA and hepatocyte mitosis. Biochem. Int. 22: 405-410

81. Jones BE, Lo CR, Liu H, Srinivasan A, Streetz K, Valentino KL and Czaja M (2000) Hepatocytes sensitized to tumor necrosis factor-alpha cytotoxicity undergo apoptosis through caspase-dependent and caspase-independent pathways. J. Biol. Chem. 275: 705-712

82. Kim WH, Hong F, Jaruga B, Hu Z, Fan S, Liang TJ and Gao B (2001) Additive activation of hepatic NF-kappaB by ethanol and hepatitis $B$ protein $X(H B X)$ or HCV core protein: involvement of TNF-alpha receptor 1-independent and dependent mechanisms. FASEB J. 15: $2551-2553$

83. Szabo G, Catalano D, Bellerose $G$ and Mandrekar P (2001) Interferon alpha and alcohol augment nuclear regulatory factor-kappaB activation in HepG2 cells, and interferon alpha increases pro-inflammatory cytokine production. Alcohol Clin. Exp. Res. 25: 1188-1197

84. Satoh S, Nussler AK, Liu ZZ and Thomson AW (1994) Proinflammatory cytokines and endotoxin stimulate ICAM-1 gene expression and secretion by norma human hepatocytes. Immunology 82: 571-576

85. Gabay C, Porter B, Guenette D, Billir B and Arend WP (1999) Interleukin-4 (IL-4) and IL-13 enhance the effect of IL-1beta on production of IL-1 receptor antagonist by human primary hepatocytes and hepatoma HepG2 cells: differential effect on C-reactive protein production. Blood 93: 1299-1307

86. Lagadic-Gossmann D, Lerche C, Rissel M, Joannard F, Galisteo M, Guillouzo A and Corcos $L$ (2000) The induction of the human hepatic CYP2E1 gene by interleukin 4 is transcriptional and regulated by protein kinase $\mathrm{C}$. Cell Biol. Toxicol. 16: $221-233$

87. Park JW, Gruys ME, McCormick K, Lee JK, Subleski J, Wigginton JM, Fenton RG, Wang JM and Wiltrout RH. (2001) Primary hepatocytes from mice treated with IL-2/IL-12 produce T cell chemoattractant activity that is dependent on monokine induced by IFN-gamma (Mig) and chemokine responsive to gamma-2 (Crg-2). J. Immunol. 166: 3763-3770 